\title{
The Context of Situation and Perlocutionary Acts Used in the Movie "Freaky Friday"
}

\author{
A.A. Ayu Krisnadiari \\ English Department - Faculty of Arts - Udayana University \\ [ayukrisnadiari@gmail.com]
}

\begin{abstract}
The title of this undergraduate thesis is The Context of Situation and Perlocutionary Acts Used in the Movie "Freaky Friday". The discussion of this study is focused on the context of situation influencing perlocutionary acts and the types of perlocutionary acts in the movie 'Freaky Friday'. The data of this study were taken from the movie 'freaky Friday". This movie is very interesting because the story is good and it presents amazing utterances. Because of that, it is worth to be analyzed. The data were collected by observing and watching the movie intensively to find out the script of the movie as secondary data, then reading the script of the movie. Furthermore, all the dialogues as the data related to speech acts were transcribed. In analyzing the data, first, identifying the utterances after that categorizing them into speech act component the next thing to do was analyzing the context of situation influencing the perlocutionary acts. Second, analyzing the types of perlocutionary acts. There were two theories used to analyze the data. First, the theory of Speech Acts proposed by Austin which was used to analyze the Perlocutionary Acts, and the second one was the theory of Ethnography of Communication proposed by Dell Hymes. The theory was used to analyze the Context of Situation influencing the perlocutionary acts. The result of this study shows that there are six types of perlocutionary acts found in this movie; they are making someone angry, intimidating, scaring, embarrassed, irritating, and persuading. Also, the context of situation takes an important part because it influences the action from the hearer.
\end{abstract}

Keywords: speech act, context of situation, types of perlocutionary acts.

\begin{abstract}
Abstrak
Judul tesis sarjana ini adalah "The Context of Situation and Perlocutionary Acts Used in the movie "Freaky Friday"”. Pembahasan penelitian ini difokuskan pada konteks situasi yang mempengaruhi perlakukan perlokusi dan jenis tindakan perlokusi dalam film 'Freaky Friday'. Data penelitian ini diambil dari film "Freaky Friday". Film ini sangat menarik karena ceritanya bagus dan menyajikan ucapan yang menakjubkan. Karena itu, perlu dianalisis. Data tersebut dikumpulkan dengan mengamati dan menonton film secara intensif untuk mengetahui naskah film sebagai data sekunder, kemudian membaca naskah filmnya. Selanjutnya, semua dialog sebagai data yang terkait dengan tindak tutur ditranskripsi. Dalam menganalisis data, pertama, mengidentifikasi ujaran setelah mengkategorikannya menjadi komponen tindak tutur, hal berikutnya yang harus dilakukan adalah menganalisis konteks situasi yang mempengaruhi tindakan perlokusi. Kedua, menganalisis jenis tindakan perlokusi. Ada dua teori yang digunakan untuk menganalisis data. Pertama, teori Speech Acts yang diajukan oleh Austin yang digunakan untuk menganalisis Perlocutionary Acts, dan yang kedua adalah teori Ethnography of Communication yang diajukan oleh Dell Hymes. Teori ini digunakan untuk menganalisis Konteks Situasi yang mempengaruhi tindakan perlocutionary. Hasil dari analisis ini, ada enam jenis tindakan perlokusi yang ditemukan di film ini seperti
\end{abstract}


menggerakkan seseorang untuk marah, mengintimidasi, menakut-nakuti, malu, iritasi, dan membujuk. Juga, konteks situasi mengambil bagian penting karena mempengaruhi tindakan daripendengar.

Kata kunci: tindak tutur, konteks situasi, jenis tindakan perlocutionary.

\section{Background of the Study}

According to Yule (2000:47), people always communicate with others using language and the ability of the people in communicating to each other is different. They have the weakness and the strength of the communication in uttering statements or information. It does not only need the understanding of the utterances but also the comprehension of the implicit meaning of those utterances. Therefore, it has the relation to the speech act which makes the speaker utter something and the responses of the hearer after hearing something. Speech acts are the acts of communication. It is proposed by Austin (1962, in Lyons 1995:725). Austin states that speech act gives an explicit recognition to the social or the interpersonal dimension of languagebehavior, and provides a general framework. In a relation with speech act, Austin (1962, Lyons 1995:730) divides Speech Act into three categories; A locutionary act is the act of 'saying something' in the full normal sense to do something. Illocutionary act is utterance which has certain or conventional force. The perlocutionary act is the effect of the act on the hearer.

\section{Problems of the Study}

a. How does the context of situation influence perlocutionary acts in the movie 'freaky friday'?

b. What are the types of perlocutionary acts found in the movie 'freaky friday'?

\section{Aims of the Study}

a. To analyze the context of situation which influences perlocutionary acts in the movie 'freaky friday'

b. To find out and classify the types of perlocutionary acts found in the movie 'freaky friday'

\section{4. $\quad$ Research Method}

The research methods used in writing this undergraduate thesis is divided into three parts: they are data source, method and technique of collecting data, method and technique of analyzing the data.

\subsection{Data Source}

The primary data in this study were taken from the movie "freaky Friday". This movie was released on August 6, 2003 by Walt Disney Pictures. The secondary data were taken from the dialogue of this movie.

\subsection{Method and Technique of Collecting Data}

The data were taken by observing the movie. The techniques to collect the data were as follows first; watching the movie intensively; finding out the script of the movie as a secondary data. Second, reading the script of the movie. Next, all the dialogues as data related to speech acts were transcribed.

\subsection{Method and Technique of Analyzing Data}

There are several steps taken in analyzing the data. The method used to analyze the data was the qualitative method. The data were analyzed by using one main theory, the speech acts theory by Austin (1983:199) and the context of 
situation by Dell Hymes (1972). The first thing to do in analyzing the data was identifying the utterances and then categorizing them whether they were locutionary, illocutionary, and perlocutionary acts after that, analyzing the context of situation influencing the perlocutionary acts. The utterances found from the movie were written in bold and italic types. The last thing to do was analyzing the types of perlocutionary acts.

\section{Analysis}

Nine conversations were analyzed in this study, but only some of the analysis is shown in this e-journal.

\subsection{Conversation 1}

In the car,

Tess Coleman: You know what? End of discussion. Feet down!

Anna: Alright. (She lowered her legs with a mad expression on her face)

The conversation of the first data above happened in the Tess Coleman's car. Specifically, Tess Coleman was driving a car on the highway and then she had a conversation with her daughter and son in the car.

In this scene, Tess Coleman was taking her daughter to school by driving a car. There were two participants involved in the conversations; they were Tess Coleman and Anna. Here, Tess was the speaker who gave an order or a command and Anna as the hearer to follow her mother's order. In the end of this conversation, Anna did what her mother wanted or ordered. She lowered her legs.

Tess Coleman was taking her daughter to school by driving a car. In his car, they had a conversation like Anna wanted to have piercing in her ear but her mother refused it and then they argued about it. When they were almost close to Anna's school, Tess ended their conversation by giving an order to lower Anna's feet (Act sequences).

The tone used by Anna in the data was refined. Anna's manner in this conversation was impolite. The conversation used common spoken English language. Then, the genre is the kind of the story. The genre of this movie is fantasy-comedy. Furthermore, the norms of the conversation were emphasized Anna's bad manner that was not good sitting impolite in the car while talking.

The utterance above 'You know what? End of discussion. Feet down!' is considered as locutionary act because it is the utterance itself And for the illocutionary act above, according to (Austin, 1955:94), is the illocutionary act "this is what the speaker intends to do uttering a sentence, illocutionary would include stating, apologizing, threatening, predicting, ordering and requesting. In this case, the speaker was giving order or a command to the hearer. The speaker wanted the hearer to stop talking or making any discussion and also the speaker was giving a command.

(She lowered her legs with a mad expression on her face) what Anna did in this scene was considered being perlocutionary act. The type of perlocutionary act performed by Anna was moving someone to anger.

\subsection{Conversation 2}

\section{In Anna's room}

(Harry was tapping Anna's guitar with her drum stick then Anna comes into her room and saw what Harry was doing)

Anna: What are you doing? Get out of my room! (With an angry expression) Harry: (Running out of her room by taking Anna's drum stick and then she chase Harry to take her drum stick back)

Harry: help! Mommy 
The conversation was taking place at Anna's room. In this scene, he hit Anna's guitar with her drum stick. Furthermore, Anna was getting mad with him and told him to get out of her room. The scene was informal. There were two participants in the conversation; they were Anna and Harry. Anna was the speaker and Harry was the hearer in the dialogue.

When Anna came into her room, he saw Harry (her little brother) tapping her guitar with her drum stick. Then she got mad with Harry and asked him to get out of her room, because he took her drum stick, she chased Harry to take her drum stick back. In the end of this dialogue, Anna wanted Harry to get out of her room. Then, Harry got out of her room by running away from her.

The tone used by Anna when she gave a command to Harry was very rude because she was mad with him. Anna's manner in the dialogue was harsh and Harry's manner was naughty. The conversation used common spoken English. The genre of the movie was fantasy-comedy. And the norms in this conversation emphasized Harry's naughty manner that we should not damage things that are not our own.

The utterance above 'What are you doing? Get out of my room!' was performed by Anna, she was Harry's sister as the speaker, it could be regarded as locutionary act because as mentioned previously, (Austin, 1955:94) Locutionary act is the act of 'saying something' in the full normal sense to do something which includes the utterance of certain noises. And in this dialogue, Anna was giving a command or ordering. This utterance was considered as the illocutionary act. The speaker may perform an act of making a statement or promise, issuing a command or request also suggestion, asking a question, etc.
Perlocutionary act is one of the important parts because it is the purpose of the speech act. In this case, Harry's behavior is considered as the perlocutionary act, (Running out of her room by taking Anna's drum stick and then she chases Harry to take her drum stick back). It might be said that the perlocutionary act is an effect of the act on the hearer. Types of perlocutionary act performed by Harry is irritating or moving someone to anger. Irritating is causing annoyance, impatience, or mild anger.

\subsection{Conversation 3}

In the dining room

(Anna comes into dining room with an angry face)

Tess: I spoke to your principal

Anna: what?

Tess: Just now on the phone

Anna: Where's my door, mom?

Tess: Privacy is a privilege; your door will be returned to you, Anna. If and when you can explain...

Anna: I need my door! You give me that door or I will kill myself.

Harry: oh really? Can I watch?

Anna: shut up!

Harry: (running and laughing)

Tess: Harry! Anna! (Yelling) I think we can dispense with the drama. And maybe you can calmly explain to me why you were in detention twice today? And enough to know that you got an "F" in English today.

Anna: well, Mr. Bates is out to get me.

The third dialogue was taking place at the dining room. In this dialogue, Tess was taking away Anna's room door then Anna getting mad with her and tried to intimidate her mother to take back her door. There were three participants in this conversation. They were Tess, Anna, and Harry.

Anna came into dining room with an angry face to protest her mother 
(Tess) because her room's door was gone or taken away by her mother. At the dining room Anna argued with her mother to take back her door even she was intimidated her mother by saying she would kill herself. Then, her mother explained to her that she would return her door if Anna could calmly explain why she was in detention twice for each day and why she got an ' $F$ ' in her English test. However, Anna just answered about her English test. In the end of this conversation, Tess was asking many questions to Anna for what's happened to her in school, her English test was ' $F$ ' and why she got in detention twice in her school for each day. Finally, Anna just answered about her English test.

The tone used by Anna in this conversation was very loud. The tone used by Tess was a bit loud but not as loud as Anna's. And then their manner in this conversation was impolite. The conversation used common spoken. The genre of the movie is fantasy-comedy. And the norms in this dialogue mare that that it is not good to intimidate someone to achieve an intention because it is one of bad attitudes.

Privacy is a privilege; your door will be returned to you, Anna. This utterance is considered to be an illocutionary act. The type of illocutionary act in this utterance is stating. In this statement Tess's utterance is considered as illocutionary act because Tess wanted her daughter (Anna) to explain to her for what had happened to Anna in school. It is also a locutionary act, because the locutionary act actually is the utterance itself in normal sense.

In this case, I need my door! You give me that door or I will kill myself. The utterance above can be regarded as perlocutionary act and the type of perlocutionary act in this utterance is intimidating. Intimidating is frightening or overawing (someone), especially in order to make them do what one wants.

\subsection{Conversation 4}

In Tess's office

Evan: (Humming) (With scary face)

Tess: (Come into her office) Evan, I'm so sorry. I had some car trouble.

Evan: ok. I thought you forgot about me.

Tess: I could never forget about you, Evan. I see you every day.

Evan: what about tomorrow? Is this new? (Looking at the flowers in the vase), Am I gonna see you tomorrow?

Tess: you're gonna see me tomorrow, but not next week because I'm going on my honeymoon.

Evan: oh my God! You're not coming back. All my therapists quit on me.

Tess: I'm not gonna quit on you. I'm gonna be available on my cell phone.

The fourth conversation was taking place in the Tess's office. In this scene, Tess was Evan's psychiatrist. Here, Evan felt scared or worried about his psychiatrist (Tess) because she told Evan that she would be honeymooning; therefore, he thought that it would be hard to meet her to continue his therapy. There were two participants in this dialogue. They are, Tess and Evan.

Tess came into her office and saw her patient (Evan) sitting in front of her room office by humming and looked so scared. Then, she said sorry to Evan because she had some car trouble. Furthermore, Evan thought that Tess forgot him and also he thought that it would be hard to meet her to continue his therapy because Tess said that she would be honeymooning. Finally, Tess answered that she would not quit on him and she would be available on her cell phone if Evan wanted to ask something emergency about his therapy (Act sequences).

In this case, the tone used by Evan was a bit shaky when he spoke to 
his psychiatrist and the tone used by Tess was refined. Then, their manners are; first, Evan was a coward, careless but he was a polite person. Second, Tess was person in charge and cared for everybody. The conversation used common spoken English. The genre of the movie is fantasy-comedy. The norm in this conversation was that we should care for each other.

Two utterances were found in this dialogue considered to be illocutionary act. Evan, I'm so sorry. I had some car trouble. The type of illocutionary act found in the utterance above is apologizing. This means that Tess apologized to Evan because she's late to come to her office due to some car trouble. And the second utterance is you're gonna see me tomorrow, but not next week because I'm going on my honeymoon. The type of illocutionary act in this utterance is stating. It is also locutionary act, because the locutionary act is the utterance in this dialogue.

The perlocutionary act is an effect of the act on the hearer. There are also two utterances found in this dialogu considered to be perlocutionary acts. They are: ok. I thought you forgot about me. And oh my God! You're not coming back. All my therapists quit on me. The type of perlocutionary acts found from those two utterances is scaring. Scaring is a time or condition of alarm or worry. In this dialogue, Evan felt scared or worried because his psychiatrist (Tess) would go on her honeymoon then it would be hard to meet her to continue his therapy.

\section{Conclusions}

Context of situation takes an important part because the context of situation influences the speaker's utterance and the action made by the hearer. It is shown from the certain scene in the movie 'Freaky Friday'. The scene reflected the action made by the hearer after the speaker said something. The speaker often said different utterances but it has the same meaning. Therefore, the hearer had to be more sensitive with the meaning of the speaker's utterances.

From the analysis, it is found that perlocutionary act cannot stand alone without locutionary and illocutionary acts. In this study, the explanation of perlocutionary act becomes more detailed because this study also discussed the types of perlocutionary act. The perlocutionary act is an effect of the act on the hearer. In saying something, we will often or even normally produce certain consequential effects upon the feeling, thoughts, or action of other, e.g. persuading someone to do something, greeting someone to believe that something is so, etc. The types of perlocutionary act in this study are persuading, embarrassing, intimidating, boring, irritating, scaring, moving someone to anger, consoling someone in his distress and enlightening. There are six types of perlocutionary acts found in this movie such as moving someone to anger, intimidating, scaring, embarrassing, irritating, and persuading.

\section{References}

Faidhah, Achmada. 2014. The Analysis of Illocutionary Act of The Novel 'Port Royal' By Linda Chaikin (tesis). Salatiga: English Department of Educational Faculty State Institute for Islamic Studies. Available from: perpus.iainsalatiga.ac.id/docfiles/f ulltext/4576994352.pdf

Austin, John L. (1962). How To Do Things With Words.

Gisladottir, R S (2015) "Conversation Electrified: ERP Correlates of Speech Act Recognition in Underspecified Utterances: 
e0120068". Available from:

Search.proquest.com

Slotta, J. Sept, 2015. "The

Perlocutionary is Political:

Listening as Self-Determination in

a Papua New Guinean Polity"

Available from:

Search.proquest.com

Wayan Nurani, Ni. 2010. Speech act component in the movie 'the proposal' (tesis). Denpasar:

Universitas Udayana. 